\title{
The Role of Accrual Estimation Errors to Determine Accrual and Earnings Quality
}

Javad Izadi Zadeh Darjezi ${ }^{1}$

\begin{abstract}
Managers, investors and security analysts all pay special attention to the bottom line of income statements and they miss significant information included in accruals about the quality of earnings. A considerable portion of the earnings-quality literatures examines the possibility of using the accruals to shift reported income among fiscal periods. One of the main roles of working-capital accruals is to adjust the recognition of cash flows. This paper focuses on earnings quality by examining the workingcapital accruals quality using the method of Dechow and Dichev (2002). The role of accrual estimation errors is essential and the result shows that the quality of accruals and earnings can decrease the magnitude of estimation error in accruals. To investigate the role of accruals, an empirical measure of accrual quality is driven to find the residuals from firm-specific regressions of changes in working capital and future cash flow from operations. The paper contributes to the literature on accruals quality by focusing on the quality of some working-capital items and visible firm characteristics and the result shows that the measure of accrual quality which is used in this paper is positively related to earnings persistence based on the UK data.
\end{abstract}

Key words: Working Capital Accruals, Earnings Quality, Estimation Errors

\footnotetext{
$\left.{ }^{1}\right)$ Corresponding author, Lecturer in Accounting and Finance, Claude Littner Business School, University of West London,
} TW8 9GA, E-Mail: Javad.Izadi@uwl.ac.uk 


\section{Introduction}

A growing body of evidence specifies that the quality of accounting information is viewed as dominant by financial analysts, investors, standards setters and other users and by firms keen to reduce information asymmetry costs by improving accounting quality. Concerning the academic literature about accounting information quality, there is no any specific definition or framework for determining the quality of earnings. However, Dechow et.al (2010) provide a definition of earnings quality by referring to SFAC No. 1 as follows:

"Higher quality earnings provide more information about the features of a firm's financial performance that are relevant to a specific decision made by a specific decision-maker."2

According to their definition of earnings quality, they believe that earnings quality is a conditional concept and is only defined in this context. Also, they argue that, in the reported earnings figure, the quality of earnings be subject to the instructive of the firm's financial performance and that earnings quality is determined by both the relevance of the underlying financial performance and the ability of the accounting system to measure performance. Researchers argue for the importance of earning quality in various ways. A multi-dimensional concept of accounting quality arises through most researchers focusing on the quality of accounting information by searching different aspects of earning in line with their interpretation of what are important aspects of earnings such as accruals quality and earnings quality. For example, Liu and O'Farrell (2011) show that there is a considerable amount of evidence which indicates the quality of earnings can be driven by new accounting standards. They find that the earnings management through accruals decreased after using the new set of standards in China. Similar to prior findings, Liu et al. (2014) demonstrate that earnings management through accruals is not significantly different between US GAAP and IAS/IFRS firms. According to earlier research, earnings management has a strong association with earnings quality. Ball and Shivakumar (2007) show that high quality earnings are conservative, whereas upwardly managed earnings are low quality earnings. A similar recommendation was made by $\mathrm{Hu}$ et al. (2015), who predicted that managers are conservative to manage earnings when they first start to take top managerial positions. According to their research, when mangers reach the maximum level of earnings management, again they will become conservative. Recent research by Cheng et al. (2013) discuss how the earnings quality can affects the role of earnings and cash flows for valuing a company. Their finding shows when earnings quality is better, the role of earnings in describing contemporaneous abnormal returns remains unchanged but operating cash flows explain more contemporaneous abnormal. Also, earlier research shows that the mispricing of accruals is greater for firms if they have a long operating cycle (see Hao, 2009). Hao finding indicates that

\footnotetext{
${ }^{2}$ Following Statement of Financial Accounting Concepts ( SFAC) standard No. 1, financial reporting should provide information as follows:

"Financial reporting should provide information about an enterprise's financial performance during a period."
} 
investors focus on earnings, whereas ignoring the persistence of accruals between firms with different earnings quality. Francis et al. (2004) provide several dimensions of earnings quality which they use widely in accounting research. Considering underlying assumptions of financial reporting, they provide seven earnings attributes according to two bases of accounting and market which is defined as "accounting-based" and "market-based". They refer to quality, persistence, predictability and smoothness as "accounting-based" because they are measured using accounting information only. Also, they consider value relevance, timeliness and conservatism as "market-based" earnings attributes because measures of these constructs are based on the estimated relation between accounting earnings and market prices or returns. The accounting-based earnings elements include accruals quality, predictability, persistence and smoothness. Value relevance, conservatism and timeliness are the elements of the market-based characteristics. The elements of the market-based characteristics use prices or returns as the reference and for their estimation they depend on both accounting data and market data. According to Francis et al. (2004), in the accounting-based elements, it is assumed that the function of earnings is to allocate cash flows to reporting periods through accruals. However, in the market-based elements, it is considered that the function of earnings is assumed to show economic income as characterised by stock returns. This paper seeks accounting-based earnings quality and consequent accruals quality as a measure of earnings quality. Accruals quality leads us more closely into cash flows to find a better view of earnings quality. The measure of earnings quality captures the planning of accruals in last, current and next-period cash flows from operations (see Dechow and Dichev, 2002). According to Dechow and Dichev findings, measure of accrual quality can capture the mapping of current accruals into last, current and next-period cash flows from operations. It means the earnings of firms with high accrual quality become cash more quickly than other firms with lower accrual quality. Also, another view of the accrual quality measure concerns the changeability of the residuals (e.g., Ball and Shivakumar, 2008, Dopuch et al., 2011). According to this idea, systematically large or small residuals of accruals regression on cash flows cannot provide an implication problem for investors since the systematic component of the residual can be adjusted. In addition, the standard deviation of a series of systematically large positive residuals may be low, which indicates that there is little extrapolation problem. Thus, accruals quality is in line with the view that high-mean, low-variance firms have strong earnings quality. In this paper focusing on persistence as a measure of earnings quality, which is predicated on the interpretation that more sustainable earnings are of greater quality and measure earnings persistence as the slope coefficient estimate. This paper follows the empirical measure of accruals quality, which is the magnitude to which working capital accruals lead us into cash flow from operation. The perception of this measure is suggested by many theoretical and practical researches which indicate that the beneficial role of accruals can be reduced by several limitations such as estimation errors. Palepu et al. (2000) provide evidence which shows that estimation errors can reduce accounting quality. Also, they suggest that estimation accuracy depends on firm characteristics such as predictability. Dechow and Dichev (2002) extend this idea into a practical measure of accrual 
and earnings quality. They provide a new approach to estimate the quality of accruals, as an example which is related to earlier researches ${ }^{3}$. The accrual-quality measure mainly focuses on the mapping of current accruals into previous, current and next-year cash flows from operations.

An example of the importance of roles of accrual accounting that is discussed in several studies (e.g., Dechow, 1994; Dechow et al., 1998) is to make parallel the timing of revenue and expense recognition based on the matching rule. Accountants add accruals to operating cash flow and make an earnings variable which is less noisy than operating cash flow. More noise in operating cash flow arises from manipulative variation in working-capital items, e.g. accounts receivable, prepayments and inventory. Also, earnings are less noisy than operating and investing cash flows, the reason being that the depreciation accounting soothes the volatility in investment outlays. The use of abnormal accruals helps to reflect reporting influences on earnings quality, not characteristic influences. Francis et al. (2008) argue that several characteristics stated by Dechow and Dichev (2002) and other researchers use some factors such as the standard deviation of sales, cash flows or firm size (as measured by the log of total assets). For example, Dechow and Dichev show the standard deviation of the residuals can be used as a firm-specific measure of accrual quality, where a lower standard deviation indicates higher quality. Also, they show $52 \%$ of the variation in the measure of accruals quality explains normal variations in accruals arising from the firm's business model and operating environment. Many researchers use "quality" measures resulting from the Dechow and Dichev model to examine numerous economic hypotheses (e.g. Biddle and Hillary, 2006; Raman et al., 2008) focus on the association between information quality and investment efficiency ${ }^{4}$. Some others investigate the association between information quality and the cost of capital, e.g. Ecker et al. (2006). Since the Dechow and Dichev (2002) model was widely adopted in accounting, there has been a scarcity of researches on the analytical and empirical validity of the model. For example, Wysocki (2009) argues that it is unclear whether the model can reliably capture the "accounting quality" of US and other international firms. He provides analytical and empirical tests of the Dechow and Dichev regression model and his finding shows that this model has a limited ability to differentiate between manipulated and "high quality" accruals. Also, he demonstrates that the model often displays empirical properties that are unclear from a random decomposition of working capital accruals and finally he believes that empirical validations of the model have some limitations. This paper proceeds as follows. The next section presents the model of accrual quality, and Section 3 describes sample selection and descriptive statistics. Section 4 develops the empirical measure of accrual quality and explores the association between accrual quality and firm

\footnotetext{
${ }^{3}$ Earlier studies, e.g. Dechow et al.(1998), Liu et al. (2002), argue about the benefits of the accrual process and find that earnings is a better measure of performance than underlying cash flows.

${ }^{4}$ Some examples of several papers that use the Dechow and Dichev (2002) model to capture accounting quality are as follows; Ashbaugh and LaFond (2003), Bhattacharya et al. (2007), Bharath et al. (2008), Bradshaw and Miller (2005), Cheng et al. (2005), Ecker et al. (2006), Francis et al. (2004 and 2005), Francis, Nanda and Olsson (2008), Francis, Olsson and Schipper (2005), Myers et al. (2003), Pae (2005), Peng (2005), and Thornton and Webster (2004).
} 
characteristics. Section 5 explores the association between accrual quality and earnings persistence A summary and concluding remarks are provided in the section 6 .

\section{Commentary on the State of the Literature}

The accruals quality and earnings process advocates that the size of estimation errors is related to business systematically. Following the Dechow and Dichev (2002) model, the result of this paper shows that accruals quality is related to the absolute magnitude of accruals negatively. Also, the standard deviation of accruals, cash flows, sales and earnings is positively related to firm size. The result demonstrates and suggests that these observable firm characteristics can be used as instruments for measuring accruals quality. According to this framework, it is expect that the larger the unsigned abnormal accrual measure, the lower the earnings quality. Therefore, firms with low accrual quality have more accruals that are unrelated to cash flow realisations and so have more noise and less persistence in their earnings. Consistent with the earlier researches, this paper finds a strong positive relation between accrual quality and earnings persistence. The paper focuses on the working-capital accruals model because cash-flow realisation is related to working-capital accruals and it occurs during a year. According to the definition of working-capital accruals, following the modified Jones model (1991) and the methodology developed by Teoh et al. (1998b), working-capital accrual is calculated as follows:

$$
W A C_{t}=\frac{\Delta\left(C A_{t}-C S I_{t}\right)-\Delta\left(C L_{t}-S T D_{t}\right)}{T A_{t-1}}
$$

Where: $A C C_{t}$ is current accruals; $C A_{t}$ is total current assets; $C S I_{t}$ is cash and short-term investments; $C L_{t}$ is total current liabilities; $S T D_{t}$ is short-term debt and current portion of long-term debt; $T A_{t-1}$ is total assets from the last period; $\Delta$ : the change in a variable.

Dechow and Dichev (2002) simply define the determinants of working-capital accruals in period $t$ as:

$$
A_{t}=C F_{t-1}^{t}+\left(C F_{t}^{t+1}+C F_{t}^{t-1}\right)+C F_{t+1}^{t}+\varepsilon_{t+1}{ }^{t}+\varepsilon_{t}^{t-1}
$$

Where: At is working capital accruals in period $t, \mathrm{CF}$ is the cash flow received or paid in period $t$ but accepted in income in period $t+1$. The error terms, net cash $t+1$ and $\varepsilon_{t}^{t-1}$ are adjustments for estimation errors and their corrections. If all cash-flow components, including $C F, C F$ model: $t 1 t+1, C F t t-1$, and $C F t+1 t$, are observable at that time, then the following regression $t$ - model can be estimated:

$$
A_{t}=\beta_{0}+\beta_{1} * C F_{t-1}^{t}+\beta_{2} *\left(C F_{t}^{t+1}+C F_{t}^{t-1}\right)+\beta_{3} * C F_{t+1}^{t}+\varepsilon_{t}
$$

Focusing on the ability to detect estimation errors in accruals is provided in Equation 3. They discuss, without considering any estimation errors and measurement errors, the estimated coefficients of equation (3) should be $\beta_{1}=\beta_{3}=1$, and $\beta_{2}=-1$. Furthermore, the regression should be $100 \%$ and residual 
variance should be zero. In Equation (3), if the classifications of the cash-flow transactions are exogenous, then it is expected that the unexplained portion of working-capital accruals in period $t$ should be related to either estimation errors, discretionary accrual choices, or even both. The Dechow and Dichev (2002) model, in particular, can capture the elements of non-discretionary accruals, NDAt, as:

$N D A_{t}=f\left(C F_{t-1}^{t}+C F_{t}^{t+1}+C F_{t}^{t-1}+C F O_{t+1}^{t}\right)$

There is no way to empirically estimate the theoretical version of their model (i.e., Equation (3). This limitation arises, because public financial firms'reports do not cover enough information to determine the cash flows directly related to working-capital accruals (i.e., $C F_{t-}$ ${ }_{l}^{t}, C F_{t}^{t+1}, C F_{t}^{t-1}$, and $\left.C F_{t+1}^{t}\right)$. Thus, one must estimate regression model (3) using substitute cashflow measures that are available. Generally, the empirical regression model is provided as follows:

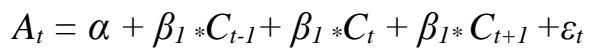

Where: $C t-l$ is lagged, $C t$ is current and $C t+l$ is next-period cash-flow measures; $A t$ is working-capital accruals in period $t$ defined as CFt-1t $-C F t t-1-C F t+1+C F t+1 t$; and $C F j k$ are cash flows received/paid in period $j$, but recognised in net income in period $k$. Wysocki (2009) examines the above equation, assumes that all variables are measured relative to their mean and shows that $(\alpha)$ the regression intercepts is equal to zero. Given that the OLS normal equations of regression model (5) give the estimated coefficients for $\beta_{1}, \beta_{1}$, and $\beta_{1} 3$ as follows:

$$
\begin{gathered}
\hat{\beta}_{1}=\frac{\delta\left(A_{t}, C_{t-1}\right)-\hat{\beta}_{2} \delta\left(C_{t-1}, C_{t}\right)-\hat{\beta}_{3} \delta\left(C_{t-1}, C_{t+1}\right)}{\delta^{2}\left(C_{t-1}\right)} \\
\hat{\beta}_{2}=\frac{\delta\left(A_{t}, C_{t}\right)-\hat{\beta}_{1} \delta\left(C_{t-1}, C_{t}\right)-\hat{\beta}_{3} \delta\left(C_{t}, C_{t+1}\right)}{\delta^{2}\left(C_{t-1}\right)} \\
\hat{\beta}_{3}=\frac{\delta\left(A_{t}, C_{t+1}\right)-\hat{\beta}_{1} \delta\left(C_{t-1}, C_{t+1}\right)-\hat{\beta}_{3} \delta\left(C_{t}, C_{t+1}\right)}{\delta^{2}\left(C_{t+1}\right)}
\end{gathered}
$$

The estimated variance of the regression residuals, $e_{t}$, is:

$$
\hat{\delta}^{2}\left(e_{t}\right)=\frac{1}{N-1\left(C_{t+1}\right)} \sum e^{2}=\frac{1}{N-1}\left[\sum A_{t}^{2}+\hat{\beta}_{1} \sum A_{t} C_{t-1}-\hat{\beta}_{2} \sum A_{t} C_{t}-\hat{\beta}_{2} \sum A_{t} C_{t+1}\right]
$$

According to the Dechow and Dichev (2002) equation framework, higher accruals quality arises from a lower residual variance. Given that, the explanatory power of the regression $\left(R^{2}\right)$ can be articulated in Equation (6) as follows: 


$$
R^{2}=\frac{\sum \mathrm{A}_{t}^{2}-\sum \mathrm{e}_{t}^{2}}{\sum \mathrm{A}_{t}^{2}}
$$

For practical measures of working capital accrual quality, Dechow and Dichev (2002) used the firm-level time-series regression as follows:

$$
W A C C_{t}=\beta_{0}+\beta_{1} C F O_{t-1}+\beta_{l} C F O_{t}+\beta_{1} C F O_{t+1}+\varepsilon_{t}
$$

Equation (7) indicates three aspects: first, accruals are temporary adjustments to anticipate the recognition of realised cash flows plus an estimation error term; second, accruals are negatively related to current cash flows and positively related to past and future cash flows; third, the error term can capture the extent to which accruals map into cash-flow realisations. This paper uses the above firmlevel time-series regression to derive practical measures of working-capital accrual quality.

\section{Sample Selection and Descriptive Statistics}

In this paper, the financial data sets are gathered from Thomson One Banker and Worldscope. The sample covers all active firms selected from year-end accounting results for UK-listed companies. Our sample comprises all companies listed on the UK market. Financial firms are removed from the sample. Also, non-standard reporting periods are excluded from the sample. The remaining firm years (after lag operations) with a complete set of observations are considered as final data observation. This paper draws attention to the firms' operating performance and focusing on profitability before interest and taxes. All variables are measured at the end of each year from 2000 to 2009. Regardless of when a firm's fiscal year ends, all firms are included in the sample with available data.

Descriptive statistics are provided in Table 1, Panel A. An examination of Table 1 shows that descriptive statistics are consistent with prior researches and with those of other researches using similar variables, e.g. Sloan (1996), Barth et al. (2001) and Dechow and Dichev (2002). Earnings during the year exceed cash flow from operations, given that, as expected, the short-term accruals are mostly positive. This is not astonishing, considering that most firms are growing and therefore increasing their working capital. Average accruals are negative (-0.038) and this is consistent with the research of Dechow and Dichev (2002). Panel A shows that the means and medians of $C F$ are positive as is the median of Earn and both aggregate accruals. In contrast, Accruals $=$ Earn $-C F$, are negative because of the negative mean and median for accruals, reflecting the fact that aggregate accruals includes depreciation and amortisation.

Panel B of Table 1 provides Pearson and Spearman correlation results. Consistent with prior research, e.g. Dechow and Dichev, the relations between our sample variables provide comparability with previous research. Results for both Spearman and Pearson correlations are similar. The correlation result in Panel B reveals that, as expected, there is a positive correlation between Earn and $C F O(0.79)$ and between Earn and WACC (0.35) and a negative correlation between $C F O$ and WACC (-0.18). Given that ccruals and WACC are positively correlated, this suggests that working-capital accruals capture the variation in total accruals. Untabulated statistics indicate that Earn, Accruals and $C F O$ are 
significantly auto-correlated. Similar to prior researches, e.g. Barth et al. (2001) and Dechow and Dichev (2002), our result shows that earnings and changes in working-capital accruals can anticipate future cash flows from operations. In addition, results in Panels A and B, which consist of descriptive statistics and correlation results, are consistent with the existing results and indicate that the equation used in this study captures some of the feathers of accrual accounting. 
Table 1. Descriptive Statistics and

Pearson and Spearman Correlations

Panel A: Descriptive Statistics

\begin{tabular}{llrrrrrrr}
\hline & & Mean & Std. Dev. & $\begin{array}{l}\text { 25th } \\
\text { Percentiles }\end{array}$ & Median & $\begin{array}{l}\text { 75th } \\
\text { Percentiles }\end{array}$ & Skewness & Kurtosis \\
\hline Earnings before extraordinary items & Earn & -0.011 & 0.115 & -0.665 & 0.022 & 0.222 & -2.333 & 10.573 \\
Earnings before long-term accruals & Earn_B & 0.028 & 0.174 & -0.906 & 0.068 & 0.390 & -1.835 & 8.185 \\
Cash flow from operations & CFO & 0.027 & 0.168 & -0.898 & 0.063 & 0.375 & -1.957 & 9.028 \\
Change in working-capital accruals & WACC & 0.001 & 0.085 & -0.356 & 0.002 & 0.343 & -0.199 & 6.166 \\
Accruals & Earn-CFO & -0.038 & 0.116 & -0.443 & -0.046 & 0.483 & 0.692 & 6.546 \\
\hline
\end{tabular}

Note: Earnings before extraordinary (Earn) is item 01551 from Worldscope. Cash from operations $(C F O)$ is used from Worldscope item. This paper follows Dechow and Dichev (2002) and calculates Earnings before long-term accruals by adding cash flow from operations and changes in working capital accruals $(C F O+W A C C)$. Variable WACC shows the change in working capital (current) accruals and is calculated as follows;

$$
A C C_{t}=\frac{\Delta\left(C A_{t}-C S I_{t}\right)-\Delta\left(C L_{t}-S T D_{t}\right)}{A V E . T A_{t}}
$$

Where: $A C C_{t}$ is current accruals; $C A_{t}$ is total current assets (WS\#06615); $C S I_{t}$ is cash and short-term investments (WS\#02001); $C L_{t}$ is total current liabilities (WS\#03101); ST $D_{t}$ is short-term debt and current portion long-term debt (WS\#03051); $A V E$. T $A_{t}$ is average of total assets (WS\#02999) from the last period and current period; $\Delta$ : the change in a variable during a year. The sample consists of 2,425 firm-period observations. All variables are scaled by an average of total assets.

The number of observation for all equation is 2,454 firm-period observations.

All variables that are used as dependent or independent variables are trimmed at the $1^{\text {st }}$ and $99^{\text {th }}$ percentiles to ensure that outliers do not drive the results. 
TABLE 1. Con.

Panel B. Pearson and Spearman correlation coefficients between variables

\begin{tabular}{|c|c|c|c|c|c|c|c|c|}
\hline & Earn $_{t}$ & Earn $_{t \_} B$ & $C F O_{t}$ & $W A C C_{t}$ & $C F O_{t+1}$ & $C F O_{t-1}$ & $E A R N$ & Accruals \\
\hline Earn $_{t}$ & 1.000 & 0.700 & 0.631 & 0.155 & 0.556 & 0.523 & 0.575 & -0.097 \\
\hline $\operatorname{Earn}_{t}$ BB & 0.758 & & $\begin{array}{l}<0.001 \\
0.789\end{array}$ & $\begin{array}{l}<0.001 \\
0.354\end{array}$ & $\begin{array}{l}<0.001 \\
0.658\end{array}$ & $\begin{array}{l}<0.001 \\
0.656\end{array}$ & $\begin{array}{l}<0.001 \\
0.627\end{array}$ & $\begin{array}{r}<0.001 \\
-0.469\end{array}$ \\
\hline & $<0.001$ & & $<0.001$ & $<0.001$ & $<0.001$ & $<0.001$ & $<0.001$ & $<0.001$ \\
\hline $\mathrm{CFO}_{\mathrm{t}}$ & 0.724 & 0.878 & & -0.180 & 0.657 & 0.667 & 0.643 & -0.746 \\
\hline $\mathrm{WACC}_{\mathrm{t}}$ & $\begin{array}{l}<0.001 \\
0.123\end{array}$ & $\begin{array}{l}<0.001 \\
0.314\end{array}$ & -0.179 & $<0.001$ & $\begin{array}{l}<0.001 \\
0.065\end{array}$ & $\begin{array}{l}<0.001 \\
0.044\end{array}$ & $\begin{array}{l}<0.001 \\
0.034\end{array}$ & $\begin{array}{l}<0.001 \\
0.361\end{array}$ \\
\hline $\mathrm{CFO}_{\mathrm{t}+1}$ & $\begin{array}{l}<0.001 \\
0.580\end{array}$ & $\begin{array}{l}<0.001 \\
0.703\end{array}$ & $\begin{array}{l}<0.001 \\
0.701\end{array}$ & 0.055 & 0.001 & & $\begin{array}{r}0.094 \\
0.756\end{array}$ & $\begin{array}{r}<0.001 \\
-0.425\end{array}$ \\
\hline $\mathrm{CFO}_{\mathrm{t}-1}$ & $\begin{array}{l}<0.001 \\
0.620\end{array}$ & $\begin{array}{l}<0.001 \\
0.745\end{array}$ & $\begin{array}{l}<0.001 \\
0.755\end{array}$ & $\begin{array}{r}0.006 \\
0.034\end{array}$ & 0.614 & $<0.001$ & $\begin{array}{l}<0.001 \\
0.542\end{array}$ & $\begin{array}{r}<0.001 \\
-0.457\end{array}$ \\
\hline Earnt & $\begin{array}{l}<0.001 \\
0.593\end{array}$ & $\begin{array}{l}<0.001 \\
0.679\end{array}$ & $\begin{array}{l}<0.001 \\
0.702\end{array}$ & $\begin{array}{r}0.092 \\
0.003\end{array}$ & $\begin{array}{l}<0.001 \\
0.807\end{array}$ & 0.605 & $<0.001$ & $\begin{array}{r}<0.001 \\
-0.392\end{array}$ \\
\hline Accrualst & $\begin{array}{r}<0.001 \\
-0.052 \\
0.011\end{array}$ & $\begin{array}{r}<0.001 \\
-0.515 \\
<0.001\end{array}$ & $\begin{array}{r}<0.001 \\
-0.726 \\
<0.001\end{array}$ & $\begin{array}{r}0.882 \\
0.381 \\
<0.001\end{array}$ & $\begin{array}{r}<0.001 \\
-0.436 \\
<0.001\end{array}$ & $\begin{array}{r}<0.001 \\
-0.475 \\
<0.001 \\
\end{array}$ & $\begin{array}{r}-0.426 \\
<0.001\end{array}$ & $<0.001$ \\
\hline
\end{tabular}

Spearman correlation (above diagonal) and Pearson correlation (below diagonal) are provided in Table 2. The sample consists of 2,454 firm-period observations from 1/2004 to 12/2009. In Table 2 the P-value of each variable is provided regarding the coefficient to illustrate the level of significance.

Note; their significance levels are shown in italics. The upper right triangle data contains Spearman coefficients and the lower triangle contains Pearson coefficients. Two reported correlation coefficients, linear (e.g. Pearson) and rank (e.g. Spearman), are commonly used to measure linear and general relationships between two variables. This study focuses on Pearson (linear correlation).

All variables that are used to run Pearson and Spearman correlation coefficients between variables are trimmed at the $1^{\text {st }}$ and $99^{\text {th }}$ percentiles to ensure that outliers do not drive the results. 
TABLE 2. Regression of the change in working-capital accruals on past, current and future cash flow from operations

Panel A: Firm-specific regression

\begin{tabular}{|c|c|c|c|c|c|c|}
\hline & \multicolumn{2}{|c|}{ Lower quartile } & \multicolumn{2}{|c|}{ Median } & \multicolumn{2}{|c|}{ Upper quartile } \\
\hline & Coeff. & $t$-stat & Coeff. & t-stat & Coeff. & $t$-stat \\
\hline Intercept & 0.002 & -13.460 & -0.033 & 1.830 & 0.038 & $\overline{17.810}$ \\
\hline$C F O_{t-1}$ & 0.201 & $\begin{array}{l}<0.001 \\
6.420\end{array}$ & 0.235 & $\begin{array}{l}0.067 \\
8.430\end{array}$ & 0.151 & $\begin{array}{l}<0.001 \\
4.900\end{array}$ \\
\hline$C F O_{t}$ & -0.339 & $\begin{array}{l}<0.001 \\
-11.880\end{array}$ & -0.333 & $\begin{array}{l}<0.001 \\
-12.400\end{array}$ & -0.377 & $\begin{array}{l}<0.001 \\
-10.270\end{array}$ \\
\hline$C F O_{t+1}$ & 0.147 & $\begin{array}{l}<0.001 \\
6.440 \\
<0.001\end{array}$ & 0.143 & $\begin{array}{l}<0.001 \\
6.770 \\
<0.001\end{array}$ & 0.165 & $\begin{array}{l}<0.001 \\
8.320 \\
<0.001\end{array}$ \\
\hline
\end{tabular}

The sample in Panel A and Panel B consists of 2,425 firm-period observations. All variables are scaled by an average of total assets.

Note: their significance levels are shown in italics.

Panel B: Firm regression

\begin{tabular}{lll}
\hline \multirow{2}{*}{ Intercept } & Coeff. & $\underline{t \text {-stat }}$ \\
& 0.001 & 0.23 \\
& & 0.818 \\
$C F O_{t-1}$ & 0.176 & 11.5 \\
& & $<0.001$ \\
$C F O_{t}$ & -0.323 & -19.95 \\
& & $<0.001$ \\
$C F O_{t+1}$ & 0.143 & 11.19 \\
& & $<0.001$ \\
Adjusted R & 0.14 & \\
\hline
\end{tabular}


TABLE 3. Industry-Specific Regression Analysis of the Change in Working Accruals on Past, Current and Future Cash Flow from Operations for Firms

\begin{tabular}{|c|c|c|c|c|c|c|c|c|c|c|c|c|c|c|c|c|c|c|}
\hline \multirow[t]{2}{*}{ Variables } & \multicolumn{2}{|c|}{0001} & \multicolumn{2}{|c|}{1000} & \multicolumn{2}{|c|}{2000} & \multicolumn{2}{|c|}{3000} & \multicolumn{2}{|c|}{4000} & \multicolumn{2}{|c|}{5000} & \multicolumn{2}{|c|}{6000} & \multicolumn{2}{|c|}{7000} & \multicolumn{2}{|c|}{9000} \\
\hline & Coeff. & $\underline{t-s t a t}$ & Coeff. & $\underline{t-s t a t}$ & Coeff. & $\underline{t-s t a t}$ & Coeff. & $\underline{t-s t a t}$ & Coeff. & $\underline{t-s t a t}$ & Coeff. & $t$-stat & Coeff. & t-stat & Coeff. & $t$-stat & Coeff. & $\underline{t-s t a t}$ \\
\hline Intercept & 0.012 & 1.570 & 0.012 & 2.350 & 0.001 & 0.480 & 0.010 & 1.880 & $<0.001$ & 0.040 & -0.005 & -1.150 & 0.021 & 1.270 & -0.034 & -1.730 & -0.006 & -1.020 \\
\hline & & 0.119 & & 0.020 & & 0.633 & & 0.061 & & 0.970 & & 0.251 & & 0.215 & & 0.094 & & 0.306 \\
\hline$C F O_{t-1}$ & 0.089 & 0.980 & 0.087 & 1.740 & 0.163 & 5.880 & 0.225 & 3.880 & 0.207 & 4.840 & 0.123 & 3.490 & 0.366 & 2.820 & 0.094 & 0.340 & 0.225 & 5.510 \\
\hline & & 0.329 & & 0.083 & & $<0.001$ & & $<0.001$ & & $<0.001$ & & $<0.001$ & & 0.008 & & 0.739 & & $<0.001$ \\
\hline$C F O_{t}$ & -0.242 & -2.840 & -0.246 & -4.680 & -0.321 & -11.190 & -0.334 & -5.640 & -0.316 & -7.260 & -0.327 & -8.820 & -0.555 & -3.430 & -0.318 & -1.470 & -0.372 & -8.110 \\
\hline & & 0.005 & & $<0.001$ & & $<0.001$ & & $<0.001$ & & $<0.001$ & & $<0.001$ & & $<0.001$ & & 0.152 & & $<0.001$ \\
\hline$C F O_{t+1}$ & 0.115 & 1.690 & 0.136 & 3.610 & 0.163 & 6.990 & 0.101 & 1.860 & 0.156 & 4.620 & 0.162 & 5.440 & -0.102 & -0.850 & 0.559 & 3.070 & 0.125 & 3.370 \\
\hline & & 0.093 & & $<0.001$ & & $<0.001$ & & 0.064 & & $<0.001$ & & $<0.001$ & & 0.400 & & 0.005 & & $<0.001$ \\
\hline Adjusted R & 0.07 & & 0.12 & & 0.14 & & 0.12 & & 0.24 & & 0.15 & & 0.38 & & 0.37 & & 0.17 & \\
\hline No. observations & 128 & & 208 & & 812 & & 255 & & 194 & & 456 & & 35 & & 32 & & 334 & \\
\hline
\end{tabular}

Note: All variables that are used in the regression association between returns and other independent variables are trimmed at the $1^{\text {st }}$ and $99^{\text {th }}$ percentiles to ensure that outliers do not drive the results. Several tests were undertaken for the robustness of the results of this study. The OLS regression analysis is based on the Industry

Classification Benchmark (ICB) which includes all industry except Financials (8000) as follows: Oil \& Gas (0001), Basic Materials (1000), Industrials (2000), Consumer Goods (3000), Healthcare (4000), Consumer Services (5000), Telecommunications (6000), Utilities (7000), Financials (8000), Technology (9000).

The P-value of each variable is provided regarding the coefficient to illustrate the level of significance. All variables are scaled by an average of total assets. Note: their significance levels are shown in italics. The number of observation for all equations is 2,454 firm-period observations. 
There is a consistency with the result of Table 2 and the result provided in Table 1. As expected, changes in working-capital accruals in the current period are negatively related to current cash flow from operations. Also, working-capital accruals are positively related to past and future cash flow from operations, consistent with the results of previous researches. In Panel A of Table 2, according to the cross-sectional distribution of firm-specific coefficients, the lower and upper quartile and median are statistically significant, with t-statistics. Adjusted $\mathrm{R}^{2}$ indicates that this regression provides reasonable explanatory power for lower quartile, median and upper quartile $0.07,0.08$ and 0.1 respectively. Also, the regression for all observations is provided in Panel B of Table 2, the coefficient on current cash flows being -0.32 , though the median coefficient on past and future periods are positive 0.17 and 0.14 respectively. Results in Table 3 provide OLS regression for industry- specification, consistent with the firm specification results for each industry. A regression for each industry is provided based on the $\mathrm{ICB}^{5}$ code from Worldscope database which includes: Oil \& Gas (0001), Basic Materials (1000), Industrials (2000), Consumer Goods (3000), Healthcare (4000), Consumer Services (5000), Telecommunications (6000), Utilities (7000), Financials (8000), Technology (9000). As already mentioned, Financials (8000) is excluded from this study. The coefficient, if current CFO is -0.32 , equal with industry (4000) for pooled regression and industry (5000), is -0.33 and is similar with the other industry coefficient.

This study provides several tests of the robustness of our results. Since cash flows are related to accruals and are noisy estimates of the theoretical cash flow variables, computing error in the independent variables equation indicates the biased estimates of residuals. Cash flows associated with the working capital accruals are expected to be an independently constant proportion of cash flow from operations. Following research by Dechow and Dichev (2002), the observations are implemented on two measurements. As the first measurement, to control the effect of sales growth, the regressions reported in Table 3 are run. Moreover, by including a growth term in the regression to be defined as percentage sales growth between $-5 \%$ and $5 \%$ in this study, the meaning of the results remains the same for both stipulations. Furthermore, controlling the effect of growth does not significantly affect the relations between accrual quality, firm characteristics and persistence of earnings. As the second step, the impact of volatility is analysed in cash flow on accrual quality. The low volatility in cash flow lead us to a steady relationship between total cash flows and cash flows related to accruals. A cash-flow volatility period in the regressions analysis is comprised and run the regression on low-volatility firms only, i.e. firms with volatility in the lowest quintile. Then, the effect of special items is examined to find which ones often contain long-term accruals and affect both our measure of short-term accruals

\footnotetext{
${ }^{5}$ The Industry Classification Benchmark (ICB) code provides an industry code which was implemented as a consequence of a merger of the industrial classification of Dow Jones and FTSE. This benchmark is used for the comparison of firms through four ranked levels of industry classification.
} 
and cash flow from operations. In this study, it is assumed that cash flow from operations is related only to short-term accruals.

\section{Planning of the association between accruals quality and firm characteristics}

In this paper, standard deviation of residuals is used as an accrual-quality measurement, given that a firm with a higher standard deviation signifies lower quality ${ }^{6}$. This type of measure of accrual quality can be applied to a diversity of determinations. As a case in point, it can be used to test the association between share prices and earnings base on the market. Using accrual quality as a measure and as an alternative to a check of earnings management is another dimension which is adapted to equal quality. Management can manage earnings through accrual accounting by using an opportunistic method. Regarding the accounting system, booking an untrue receivable and not collecting it is similar to booking a steady receivable and not collecting it. Following recent research by Dechow and Dichev, two applications to measure accrual quality are used. First, the association between our measure and selected firm characteristics is discussed. It is possible that the average size of estimation errors for a firm is thoroughly related to the firm's features such as the volatility of its operations. Managers in unstable industries, even with good expertise and the best of aims, are expected to make larger estimation errors of accruals. Planning the association between estimation errors and firm characteristics is significant for research purposes. Given the use of firm-specific regression to estimate the standard deviation of the residuals value for a time-series, the regression analysis approach necessitates information related to future cash flows. Hence, focusing on firms' characteristics can produce a tendency to make estimation errors. For example, standard deviation of accruals as a firm characteristic is expected to be associated with the standard deviation of residual.

In this paper, to identify the association between estimation errors and firm characteristics, it is expected that the greater the sales volatility, the lower the accrual quality. Volatility in sales shows the volatile operating environment of firms and specifies the probability of more use of approximations and estimation, with consistently large errors of estimation and low accrual quality. Since a high standard deviation of cash flows shows high uncertainty in the operating environment, a greater size of cash flow volatility indicates lower accrual quality. Also, in this paper, the measure of accrual quality results from the residual value of accruals. Given that the greater the size of accrual volatility, the lower the accrual quality, although earnings are formed from cash flows and accruals, the volatility of both components is predicted to be negatively related to earnings quality. It is expected that greater volatility in earnings signifies lower accrual quality. In other words, a greater size of earnings volatility demonstrates lower accrual quality. Also, losses for a firm's operations are indicated as negative surprises. Accruals made as a reaction to such surprises will probably involve substantial estimation error. Therefore, losses are

\footnotetext{
${ }^{6}$ An alternative measure of accrual quality at the firm-year level is the absolute value of the residual for that year. The tenor of the results is similar for this alternative specification, but the relations to firm characteristics and earnings persistence are weaker.
} 
factors of low accrual quality, given that a greater frequency of negative earnings leads us to lower accrual quality. In addition, the high level of accruals causes more errors of estimation which present as a lower quality of accruals. Thus, more accruals indicate lower accrual quality.

According to the theory of the magnitude of volatility, the following is expected:

$H_{0:}$ More volatility in sales, cash flow, accruals and earnings make a lower accrual quality.

In Table 4 the outcomes for these hypothesised associations are provided. Descriptive statistics are provided in Panel A. Variables are scaled on a firm basis to be consistent with the firm-level measure of accrual quality. The Pearson correlations analysis between our measure of accrual quality (standard deviation of the residuals) and the firm characteristics are presented in Panel B. The coefficient and significance signs for each variable are also presented in Panel B. The result of this table shows that all variable correlations are significant (correlations have the predicted signs). The highest correlation is for the standard deviation of cash flow (0.62), the standard deviation of working capital accruals $(0.56)$ and earnings before long-term accruals (0.54). The result shows that there is a strong correlation between our variables. The correlation result table suggests that these variables can be used as reliable instruments for explaining accrual quality. Consistence with the research of Sloan (1996) and Dechow and Dichev (2002) and the high correlation level of working-capital accruals (0.56) suggests a strong association between standard deviation of the residuals and the measure of accrual quality.

Panel $\mathrm{C}$ of Table 4 examines whether combinations of the firm characteristics can capture accrual quality more than each individual variable. Given that, the regression is run base on the standard deviation of the residuals and other independent variables as firm characteristics. First, in the equation (1) Std.Dev. Earn_b, as the only independent variable, is tested with an adjusted R2 of 0.29. Then the volatility of earnings into accrual and cash-flow volatility are decomposed, both of variables which are highly correlated with Std. Dev. Residuals are shown in Panel B. The result of Equation (2) shows that Std.Dev. Earn_b and Std. Dev. WACC have an adjusted R2 of 0.43. The Equation (2) result shows that Std. Dev. WACC includes the descriptive power of Std. Dev. CFO. The volatility of earnings and working-capital accruals is presented in Equation (3), with the R2 increasing to 0.43.

\section{Planning of the Association Between Accruals Quality and Earnings Persistence}

Earnings-persistence performance depends on the sizes of the cash and of the accrual components. Some researches, e.g. Penman (2001); Revsine et al. (2002); Dechow and Dichev (2002); Dechow and Schrand (2004); and Dye and Sridhar (2007) investigate earnings persistence as a measure of earnings quality. Following Dechow and Dichev (2002), a link is formed between our measure of accrual quality and earnings persistence. As it is shown in Equation (3), holding the time-series properties of realised cash flows makes more accrual errors and results in lower earnings persistence. Hence, it is expected that firms with low accrual quality have low earnings persistence. Panel A of Table 5 demonstrates the regression results of association between accrual quality and earnings persistence. In this paper, the portfolio result is provided, similar to earlier studies such as Sloan (1996); Barth et al. (2001) and 
Dechow and Dichev (2002), to make a comparability in order to investigate for a potential nonlinear relation in the quality-persistence. First, firm-years are sorted into quintile portfolios based on the standard deviation of the firm-specific regression standard deviation of the residuals (see Panel A of Table 5). This paper follows two approaches to describe the explanatory power of the standard deviation of the residuals and the level of working-capital accruals with respect to earnings persistence. The result in Panel A shows that there is a negative relationship between the standard deviation of the residuals and the persistence measure. The persistence measure declines from 0.069 to -0.058 between quintiles 1 and 5. However, the difference between standard deviation of the residuals is increased from 0.013 to 0.053 between quintiles 1 and 5 . For variable of standard deviation of residuals, the difference between quintiles 1 and 5 is -17.847 and this is strongly significant. The difference for persistence is 10.699 and this is significant as well. Also, the absolute value of working-capital accruals has a negative relation with the measure of persistence.

In Panel B of Table 5, the mean value of the portfolio are ranked based on the magnitude of the absolute value of working-capital accruals. In Panel B, the absolute-magnitude value of working-capital accruals and the measure persistence for each quintile is provided. The results confirm the expected negative relation between the level of accruals and the earnings persistence; the measure of persistence declines from 0.041 to -0.032 and the standard deviation of residuals from 0.020 to -0.027 between quintiles 1 and 5 . The differences between mean and t-stat for the level of working-capital accruals and the standard deviation of residuals are -0.152 and -0.027 and the t-stat are -52.576 and -12.505 respectively and both are strongly significant. However, the differences between the lower and upper quintals for the measure of persistence are positive and are 0.072 and t-stat is 5.786. Furthermore, the relation between the level of accruals and persistence in Panel B is not in harmony and fundamentally is flat for a low- to medium-level of working-capital accruals. Therefore, the relationship between accrual quality and earnings persistence is stronger than that between the level of accruals and persistence. 
TABLE 4 Descriptive statistics and correlation to analyse the quality of working-capital accruals for firms.

Panel A: Descriptive Statistics

\begin{tabular}{lrrrrrrr}
\hline & Mean & Std. Dev. & $\begin{array}{r}\text { 25th } \\
\text { Percentiles }\end{array}$ & Median & $\begin{array}{r}\text { 75th } \\
\text { Percentiles }\end{array}$ & Skewness & Kurtosis \\
\hline Std. Dev. Residuals & 0.027 & 0.030 & 0.009 & 0.018 & 0.033 & 2.981 & 15.597 \\
Std. Dev. Sales & 0.126 & 0.398 & 0.040 & 0.079 & 0.141 & 25.324 & 745.876 \\
Std. Dev. CFO & 0.078 & 0.012 & 0.029 & 0.051 & 0.090 & 14.972 & 344.705 \\
Std. Dev. WACC & 0.078 & 0.087 & 0.032 & 0.055 & 0.100 & 9.306 & 175.771 \\
Std. Dev. Earn_B & 0.098 & 0.139 & 0.032 & 0.061 & 0.109 & 7.146 & 84.467 \\
Log. TA & 17.982 & 2.091 & 16.466 & 17.831 & 19.357 & 0.314 & 2.564 \\
\hline
\end{tabular}

The number of observations for all equations is 2,454 firm-period observations

Panel B: Pearson correlation

\begin{tabular}{|c|c|c|c|c|c|c|c|}
\hline & $\begin{array}{l}\text { Std. Dev. } \\
\text { Residuals }\end{array}$ & $\begin{array}{r}\text { Log. } \\
\text { TA }\end{array}$ & $\begin{array}{r}\text { Std. Dev. } \\
\text { Sales }\end{array}$ & $\begin{array}{r}\text { Std. } \\
\text { Dev. } \\
\text { CFO }\end{array}$ & $\begin{array}{r}\text { Std. Dev. } \\
\text { WACC }\end{array}$ & $\begin{array}{r}\text { Std. Dev. } \\
\text { Earn_B }\end{array}$ & $\begin{array}{r}\text { Abs. } \\
\text { WACC }\end{array}$ \\
\hline Std. Dev. Residuals & 1.000 & -0.421 & -0.115 & 0.619 & 0.557 & 0.543 & 0.359 \\
\hline Log. TA & & $<0.001$ & $\begin{array}{l}<0.001 \\
0.437\end{array}$ & $\begin{array}{r}<0.001 \\
-0.321\end{array}$ & $\begin{array}{r}<0.001 \\
-0.293\end{array}$ & $\begin{array}{r}<0.001 \\
-0.220\end{array}$ & $\begin{array}{r}<0.001 \\
-0.214\end{array}$ \\
\hline Std. Dev. Sales & & & $<0.001$ & $\begin{array}{r}<0.001 \\
-0.076\end{array}$ & $\begin{array}{r}<0.001 \\
-0.073\end{array}$ & $\begin{array}{r}<0.001 \\
-0.046\end{array}$ & $\begin{array}{r}<0.001 \\
-0.069\end{array}$ \\
\hline Std. Dev. CFO & & & & $<0.001$ & $\begin{array}{l}<0.001 \\
0.747\end{array}$ & $\begin{array}{r}0.026 \\
0.399\end{array}$ & $\begin{array}{r}0.001 \\
0.209\end{array}$ \\
\hline Std. Dev. WACC & & & & & $<0.001$ & $\begin{array}{l}<0.001 \\
0.420\end{array}$ & $\begin{array}{l}<0.001 \\
0.419\end{array}$ \\
\hline Std. Dev. Earn_B & & & & & & $<0.001$ & $\begin{array}{l}<0.001 \\
0.242\end{array}$ \\
\hline Abs. WACC & & & & & & & $<0.001$ \\
\hline
\end{tabular}

The number of observations for all equations is 2,454 firm-period observations. All variables are scaled by an average of total assets. Note: their significance levels are shown in italics. 
TABLE 4. Con.

Panel C: Regressions Where the Dependent Variables Are the Standard Deviation of the Residuals and the Independent Variables Are Firm Characteristics

\begin{tabular}{|c|c|c|c|c|c|c|c|c|c|}
\hline & \multicolumn{2}{|c|}{ Intercept } & \multicolumn{2}{|c|}{ Std. Dev. Earn_B } & \multicolumn{2}{|c|}{ Std. Dev. WACC } & \multicolumn{2}{|c|}{ Std. Dev. CFO } & \\
\hline & Coeff. & $t$-stat & Coeff. & $t$-stat & Coeff. & $t$-stat & Coeff. & $t$-stat & Adjusted R \\
\hline 1) & 0.016 & 0.015 & 0.117 & 0.110 & & & & & 0.29 \\
\hline 2) & 0.009 & $\begin{array}{l}<0.001 \\
0.007\end{array}$ & 0.081 & $\begin{array}{c}<0.001 \\
0.074\end{array}$ & 0.136 & 0.124 & & & 0.43 \\
\hline 3) & 0.013 & $\begin{array}{l}<0.001 \\
0.012 \\
<0.001\end{array}$ & & $<0.001$ & 0.067 & $\begin{array}{l}<0.001 \\
0.100 \\
<0.001\end{array}$ & 0.112 & $\begin{array}{l}0.050 \\
<0.001\end{array}$ & 0.40 \\
\hline
\end{tabular}


TABLE5. The relative information content of the Accruals quality and the level of accruals for Earnings persistence

Panel A: Portion Based On the Magnitude of the Standard Deviation of the Residuals

\begin{tabular}{|c|c|c|c|c|c|c|c|}
\hline$\underline{\text { Portfolio }}$ & $\underline{1}$ & $\underline{2}$ & $\underline{3}$ & $\underline{4}$ & $\underline{5}$ & Diff. & t.stat \\
\hline Std. Dev. Residuals & 0.013 & 0.017 & 0.022 & 0.031 & 0.053 & -0.040 & -17.847 \\
\hline Abs. WACC & 0.026 & 0.034 & 0.048 & 0.067 & 0.116 & -0.091 & $\begin{array}{l}<0.001 \\
-20.710\end{array}$ \\
\hline Persistence & 0.069 & 0.072 & 0.053 & 0.018 & -0.058 & 0.127 & $\begin{array}{c}<0.001 \\
10.699 \\
<0.001\end{array}$ \\
\hline
\end{tabular}

Panel B: Portfolios Based on the Absolute Value of Accruals

\begin{tabular}{|c|c|c|c|c|c|c|c|}
\hline Portfolio & $\underline{1}$ & $\underline{2}$ & $\underline{3}$ & $\underline{4}$ & $\underline{5}$ & Diff. & t.stat \\
\hline$\overline{\text { Abs. WACC }}$ & $0.00 \overline{6}$ & $0.02 \overline{0}$ & $0.03 \overline{7}$ & $0.06 \overline{7}$ & $0.15 \overline{9}$ & $\overline{-0.152}$ & -52.576 \\
\hline Std. Dev. Residuals & 0.020 & 0.021 & 0.023 & 0.026 & 0.047 & -0.027 & $\begin{array}{l}<0.001 \\
-12.505\end{array}$ \\
\hline Persistence & 0.041 & 0.050 & 0.043 & 0.037 & -0.032 & 0.072 & $\begin{array}{c}<0.001 \\
5.786 \\
<0.001\end{array}$ \\
\hline
\end{tabular}

Note: "WML" is defined as the mean difference between winner and loser firms and "T-Stat" demonstrates the T-Statistics of these differences. According to the returns, all stock are ranked to five levels. $<0.001$ denotes significance at the $1 \%$ level.

According to the returns, all stock are ranked to five levels. $L M W$ means losers minus winners. 


\section{Conclusion and Summary}

Dechow (1996) argues that the working-capital accruals are more important to mitigate timing and matching problems in cash flows when comparing with long-term accruals. Moreover, the research of Dechow and Dichev (2002) suggests a specifically different approach to assessing working-capital accruals and earnings quality. They provide a model to measure accrual quality as the residuals from firm-specific regressions of changes in working capital accruals and future operating cash flows.. Working-capital accruals are momentary changes that resolve timing problems in fundamental cash flows at the cost of making estimates. Accurate estimates can suggest a reasonable match between current accruals and current, past and future cash flow.

This paper follows the method of Dechow and Dichev (2002) and define accrual quality as the extent to which accruals map into cash-flow insights based on the UK data. There is a theoretical limitation for this approach with respect to the cash flows. The limitation is it provides little insight into the appropriate timing of accruals. As an example, this approach cannot be lead users to decide whether to or capitalize expense research and development expenditures. Empirical limitations for this analysis contain a restriction to working capital accruals that indicates there is no serial correlation in the estimation errors. To find the quality of working-capital accruals, the standard deviation of the residuals is used as accrual quality that resulted from firm-specific OLS regressions of working-capital accruals based on last, current and one-year-ahead operating cash flow. Unlike prior research, to avoid a restriction to working-capital accruals, different equations is used to cover more items of workingcapital accruals. In addition, after examining earnings and accrual quality, this paper finds that average UK company behaviour was quite similar to the behaviour found earlier in United States. This paper's findings show that greater volatility of sales, cash flow, accruals and earnings results in a lower accrual quality. Without a doubt, some of the analysis in this paper, especially that using different equations to calculate working-capital accruals, leads us to a valuable improvement of the earlier studies. 


\section{REFERENCES}

Ashbaugh, H., and R. LaFont, 2003. Reporting incentives and the quality of non-US firms' working capital accruals. Working paper, University of Wisconsin.

Ball, R., Shivakumar, L., 2008. Earnings quality at initial public offerings. Journal of Accounting and Economics, 45(2): 324-349.

Ball, R., and L. Shivakumar, 2008. Earnings quality at initial public offerings. Journal of Accounting and Economics, 45 (2/3): 324-349.

Barth, M., Cram, D., and K. Nelson, 2001. Accruals and the prediction of future cash flows. The Accounting Review, 76, 27-58.

Bharath, S., Sunder, J., and S. Sunder, 2008. Accounting quality and debt contracting. The Accounting Review, 83(1), 1-28.

Bhattacharya, N., Desai, H., and K. Venkataraman, 2007. Earnings quality and information asymmetry: Evidence from trading costs, working paper, Southern Methodist University.

Biddle, G., and G. Hilary, 2006. Accounting quality and firm-level capital investment. The Accounting Review, 81(5), 963-982.

Bradshaw, M., and G. Miller, 2005. Will harmonizing accounting standards really harmonize accounting? Evidence from non-US firms adopting US GAAP. Journal of Accounting, Auditing \& Finance, April 2008 vol. 23 no. 2 233-264.

Cheng, C. S. A., Johnston, J., Liu, C. Z., 2013. The supplemental role of operating cash flows in explaining share returns: Effect of various measures of earnings quality. International Journal of Accounting \& Information Management, 21(1): 53-71.

Cheng, C., Peng, H., and W. Thomas, 2005. Comparison of abnormal accrual estimation procedures in the context of investor mispricing. University of Houston, Working paper. 
Dechow, P., 1994. Accounting earnings and cash flows as measures of firm performance: The role of accounting accruals. Journal of Accounting and Economics, 18, 3-42.

Dechow, P., and I. Dichev, 2002. The quality of accruals and earnings: The role of accrual estimation errors. The Accounting Review, 77 (Supplement): 35-59.

Dechow, P., Schrand, C., 2004. Earnings quality. The Research Foundation of CFA Institute

Dechow, P., Ge, W., \& Schrand, C., 2010. Understanding earnings quality: A review of the proxies, their determinants and their consequences. Journal of Accounting and Economics, 50 (2-3): $344-401$.

Dechow, P., Kothari, S., Watts, R., 1998. The Relation between Earnings and Cash Flows. Accounting \& Economics, 25, 133-168.

Dopuch, N., Mashruwala, R., Seethamraju, C., and Zach, T., 2011. The impact of a heterogeneous accrual-generating process on empirical accrual models. Journal of Accounting, Auditing \& Finance, 27(1): 1-26.

Ronald A. Dye; Sri S. Sridhar, 2007. The allocational effects of the precision of accounting estimates. Journal of Accounting Research, 45(4):731-769.

Ecker, F., Francis, J., Kim, I., Olsson, P., and K. Schipper, 2006. A returns-based representation of earnings quality. The Accounting Review, 81(4): 749-780.

Francis, J., LaFond, R., Olsson, P., and K. Schipper, 2004. Costs of equity and earnings attributes. The Accounting Review, 79, 967-1010.

Francis, J., LaFond, R., Olsson, P., Schipper, K., 2005. The market pricing of accruals quality. Journal of Accounting and Economics, 39, 295-327.

Francis, J., Nanda, D., Olsson, P., 2008. Voluntary disclosure, earnings quality, and cost of capital. Journal of Accounting Research, 46, 53-99.

Hao, Q., 2009. Accruals' persistence, accruals mispricing and operating cycle: evidence from the US. International Journal of Accounting \& Information Management, 17(2): 198-207.

Hu, N., Hao, Q., Liu, L., Yao, L. J., 2015. Managerial tenure and earnings management. International Journal of Accounting \& Information Management, 23(1): 42 - 59. 
Jones, J., 1991. Earnings management during import relief investigation. Journal of Accounting Research, 29, 193-228.

Liu, C. and O'Farrell, G., 2011. The impact of IFRS on earnings management: evidence from the People's Republic of China. International Journal of Services and Standards, 7(3/4): 264 277.

Liu, J., Nissim, D., Thomas, J., 2002. Equity valuation using multiples. Journal of Accounting Research, 40, 135-172

Liu, C., Yuen, C. Y., Yao, L. J., Chan, S. H., 2014. Differences in earnings management between firms using US GAAP and IAS/IFRS. Review of Accounting and Finance, 13(2): 134 - 155

Myers, J., Myers, L., and T. Omer, 2003. Exploring the term of auditor-client relationship and the quality of earnings: a case for mandatory auditor rotation? The Accounting Review, 78(3): 779-799.

Pae, J., 2005. Expected accrual models: the impact of operating cash flows and reversal of accruals. Review of Quantitative Finance and Accounting, 24, 5-22.

Palepu K., P. Healy, and V. Bernard, 2000. Business Analysis and Valuation. Cincinnati, OH: South Western

Penman, S., 2001. On Comparing Cash Flow and Accrual Accounting Models for Use in Equity Valuation: A Response to Lundholm and O'Keefe. Contemporary Accounting Research, Vol. 18(4): 681-92

Raman, K., L. Shivakumar, and A. Tamayo, 2008. Targets "earnings quality and bidders" takeover decisions. London Business School, Working paper.

Revsine, L., D. W. Collins, and W. B. Johnson, 2002. Financial Reporting and Analysis. Upper Saddle River, NJ: Prentice Hall.

Sloan, R. G., 1996. Do Stock Prices Fully Reflect Information in Accruals and Cash Flows about Future Earnings? Accounting Review, 71(3): 289-315.

Teoh, S. H., Welch, I., and Wong, T. J., 1998a. Earnings Management and the Long-Run Performance of Initial Public Offerings. Journal of Finance, 53(6):1935-1974 
Thornton, D., and Webster. T., 2004. Earnings quality under rules vs. principles-based accounting standards: a test of the Skinner hypothesis. Canadian Accounting Perspectives, 4(2): 167-192

Wysocki, P. D., 2008. Assessing Earnings and Accruals Quality: U.S. and International Evidence. Revised October 2009. Working paper 